
$\angle$ Research Square
Preprints are preliminary reports that have not undergone peer review.
They should not be considered conclusive, used to inform clinical practice, or referenced by the media as validated information.

\title{
SSR Marker-Based Genetic Resource Assessment of The Rainbow Clam Moerella Iridescens Along The Coasts of China: Implications for Strategy of Conservation Management
}

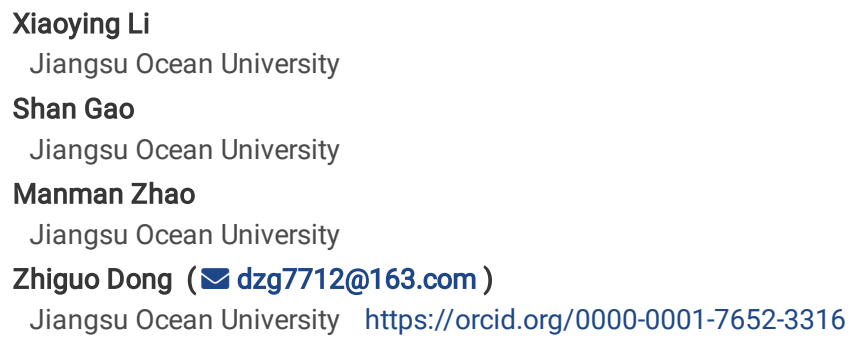

Research Article

Keywords: Moerella iridescens, SSR, Genetic diversity, China coasts, Conservation management

Posted Date: August 18th, 2021

DOI: https://doi.org/10.21203/rs.3.rs-769531/v1

License: (c) (1) This work is licensed under a Creative Commons Attribution 4.0 International License. Read Full License

Version of Record: A version of this preprint was published at Frontiers in Marine Science on February 23rd, 2022. See the published version at https://doi.org/10.3389/fmars.2022.843312. 


\section{Abstract}

This study aims to determine the genetic structure and diversity of rainbow clam Moerella iridescens in different sea areas of China. Seventeen pairs of microsatellite primers (SSR) were used to amplify the SSRs of rainbow clam in Lianyungang of Haizhou Bay, Chongming of Shanghai, Ningde in Fujian, Cixi and Wenzhou in Zhejiang. A total of 1146 alleles were detected in 310 individuals from the 17 SSR loci. The average observed heterozygosity of six populations was $0.4381-0.6139$, the average expected heterozygosity was $0.5897-0.7325$, and the average Shannon diversity index was $1.2655-1.7998$. The clams exhibited rich genetic diversity and the $F_{\mathrm{ST}}$ of the genetic differentiation index of the six populations was 0.0470 , indicating low genetic differentiation amongst the populations. The results indictated that rainbow clam along China coasts exhibited high diversity and low population differentiation.

\section{Introduction}

The rainbow clam Moerella iridescens is an economically important small-sized marine clam due to delicious taste and high nutritional value. The clam mainly is distributed in the West Pacific coast and northern Australia. In recent years, rainbow clam has been increasingly used as high-valued seafood and as feed for shrimps and crabs in some mariculture industry of China. Deterioration of the ecological environment has led to a sharp decline in the natural resources of rainbow clams due to overfishing and increases in shrimp and crab farming. Thus, protection of rainbow clam resources is of great importance. Several authors have explored the biological characteristics and morphological differences of rainbow clam (Ji et al. 2007; Lv et al. 2012). To date, however, reports on the genetic diversity and relationships amongst clam populations are limited (Xu et al. 2016).

Microsatellites, also known as simple repetitive sequences (SSR), present the advantages of co-dominance, single locus, high polymorphism and easy operation and can be screened from different populations to complete genetic diversity studies (Cui et al. 2011). Microsatellite marker technology has been widely used in the structural analysis of the population genetics of aquatic animals, e.g. the rainbow trout (Zhao et al. 2010), the scallop Patinopecten yessoensis (Chang et al. 2007) and triangle pearl Hyriopsis cummingii (Bai et al. 2015). So far, few reports are available on the genetic diversity of the population of rainbow clam. In the present study, the genetic diversity of six populations of rainbow clams in Lianyungang, Chongming Island, Ningde, Zhoushan, Cixi and Wenzhou was analysed by using microsatellite markers. The results obtained can provide a scientific basis for assessing germplasm resources and genetic diversity protection of rainbow clam.

\section{Materials And Methods}

\section{Materials}

Rainbow clams were collected from the six coastal mud flats, Lianyungang Haizhou Bay (LYG), Chongming Island Dongtan (CM), Ningde Fu'an (ND), Zhoushan Daishan (ZS), Hangzhou Bay Cixi (CX) and Wenzhou Yueqing Bay (WZ). Fifty samples were obtained randomly from each population. Information on the samples collected is presented in Table 1 and Fig. 1. The sampled rainbow clams were stored at $-70^{\circ} \mathrm{C}$ until analysis.

Table 1

Sampling time, place and sample size of rainbow clam

\begin{tabular}{|c|c|c|c|c|c|c|}
\hline Stock & LYG & $\mathrm{CM}$ & ND & ZS & $c x$ & WZ \\
\hline Sampling time & $2012 \cdot 10$ & $2012 \cdot 10$ & $2012 \cdot 10$ & $2012 \cdot 10$ & $2012 \cdot 10$ & $2012 \cdot 10$ \\
\hline $\begin{array}{l}\text { Number of } \\
\text { samples }\end{array}$ & 50 & 50 & 50 & 50 & 50 & 50 \\
\hline \multirow[t]{3}{*}{ Sampling site } & $\begin{array}{l}\text { Sanyang } \\
\text { harbor, }\end{array}$ & $\begin{array}{l}\text { East beach, Chongming } \\
\text { Island }\end{array}$ & $\begin{array}{l}\text { Xiabaishi, Sansha Bay } \\
\text { in Fu'an }\end{array}$ & $\begin{array}{l}\text { Datian } \\
\text { Bay, }\end{array}$ & $\begin{array}{l}\text { Cixi Sanbei } \\
\text { shoal,Hangzhou Bay }\end{array}$ & $\begin{array}{l}\text { Simon Island, } \\
\text { Yueqing Bay, }\end{array}$ \\
\hline & \multirow[t]{2}{*}{ Haizhou Bay } & & & Daishan, & & \\
\hline & & & & Zhoushan & & \\
\hline \multirow[t]{2}{*}{ GPS } & E119.2835 & E122.0058 & E119.6263 & E122.2095 & E121.4337 & E121.2031 \\
\hline & N34.7996 & N31.5316 & N26.7948 & N30.2888 & N30.2998 & N28.3229 \\
\hline
\end{tabular}

\section{Microsatellite Primer}

The M13 (-21) universal primer sequence of 5'-TGTAAAACGACGGCCAGT-3' reported by Schuelke (2000) was adopted in this study to elongate short primers in for economic consideration in genotyping. We used two fluorescent labels FAM and HEX for forward primes which were abbreviated as FAM-M13 and HEXM13. Totally, 19 SSRs were used for PCR and these primer information was shown in Table 2. 
Table 2

Microsatellite primer information. *Primers of forward sequence tailed with universal M13 $(-21)$ sequences $\left(5^{\prime}\right.$ -

\begin{tabular}{|c|c|c|c|c|}
\hline SSR & Repeat motif & Sequence $\left(5^{\prime}-3^{\prime}\right) *$ & Size of original fragment /bp & $(\mathrm{Tm}) /{ }^{\circ} \mathrm{C}$ \\
\hline \multirow[t]{2}{*}{ HGZ2 } & $(\mathrm{AC}) 17(\mathrm{CA}) 11$ & F:TGAGGTGGAATGAGTTAC & 124 & 45 \\
\hline & & R:TAAGTTCGGATGACAAAG & & \\
\hline \multirow[t]{2}{*}{ HGZ3 } & (GT)22 & F:ATGGGAGACAACTCGCTAC & 353 & 52 \\
\hline & & R:CTGTCACAACGGCAATCT & & \\
\hline \multirow[t]{2}{*}{ HGZ6 } & $(\mathrm{TG}) 4$ & F:GGGCCAAATCAGGGAATG & 103 & 58 \\
\hline & & R:AGCAGGAAACGCAGCACA & & \\
\hline \multirow[t]{2}{*}{ HGZ9 } & $(\mathrm{AC}) 9(\mathrm{AC}) 7(\mathrm{CA}) 7$ & F:CAGCCTGGGCAACATAGT & 116 & 53 \\
\hline & & R:TAGGACCACAGGTAAGCATC & & \\
\hline \multirow[t]{2}{*}{ HGZ10 } & $(\mathrm{GT}) 6(\mathrm{GT}) 8(\mathrm{GT}) 6$ & F:AGGTAGGGCGTGAAGGAA & 193 & 55 \\
\hline & & R:GCAAAATCGACCCTACTACATA & & \\
\hline \multirow[t]{2}{*}{ HGZ14 } & $(\mathrm{CA}) 6$ & F:ACTAGTACGTGAAGATTAGCCAA & 338 & 55 \\
\hline & & R:GAGGCGATACTCATAATGTTCA & & \\
\hline \multirow[t]{2}{*}{ HGZ17 } & $(\mathrm{AC}) 26(\mathrm{CA}) 21$ & F:ATGAGAGAGCGACAGAATG & 150 & 50 \\
\hline & & R:TAGAGGCTCCCTAAATGG & & \\
\hline \multirow[t]{2}{*}{ HGZ22 } & $(\mathrm{GA}) 19(\mathrm{AG}) 12$ & F:TTTCCACTTCGCACATTG & 196 & 52 \\
\hline & & R:CTCGCACAAACAAATGAAC & & \\
\hline \multirow[t]{2}{*}{ Mir8 } & (GT)15 & F:GTAGGTTTGGCATGGCTTTGTAGC & 124 & 64 \\
\hline & & R:ACCATTGAGGGCTCGTCTGAATTAT & & \\
\hline \multirow[t]{2}{*}{ Mir12 } & $(A G) 16$ & F:TCACCAGAAAGGAGACCGTAAAAGT & 120 & 63 \\
\hline & & R:CTACGGATTTCGCAGTGAAAATGT & & \\
\hline \multirow[t]{2}{*}{ Mir13 } & $(\mathrm{AC}) 15$ & F:GCAACACAACGAGAGTG & 116 & 47 \\
\hline & & R:ACAACAAACAACAAAGAAAT & & \\
\hline \multirow[t]{2}{*}{ Mir14 } & $(\mathrm{CT}) 4$ & F:ATCGTTGGGGCATTCTAGTTTTCT & 83 & 62 \\
\hline & & R:GGGTATAATAATTTTGAAACGCAGC & & \\
\hline \multirow[t]{2}{*}{ MH19A } & (TG)28 & F:GTGAGCAGGAATCAAAGGTG & $105-145$ & 55 \\
\hline & & R:CTCCGCTCTGTTTGCCTAT & & \\
\hline \multirow[t]{2}{*}{ Mi44A } & (TG)61 & F:CCTCGGAGACCATTCGCTAC & $85-101$ & 52 \\
\hline & & R:TGCTTTTCTATGACAACCCT & & \\
\hline \multirow[t]{2}{*}{ MW33A } & (TG)13TA(TG)5(CG)2TGCG & F:TTССТАТССТТАСССТTG & $111-171$ & 48 \\
\hline & & R:CTGACTGGAAACTCAACAC & & \\
\hline \multirow[t]{2}{*}{ MW15A } & $(\mathrm{CA}) 24$ & F:GATCAAAATTGACAAGGCT & $88-150$ & 46 \\
\hline & & R:AAGACAAACACGGATGGT & & \\
\hline \multirow[t]{2}{*}{ MX39C } & TGTT(TG)6(GG)4GT & F:CCCAACCAGAATAATACCA & $200-220$ & 48 \\
\hline & & R:TCCAACAAAGGAATACGATA & & \\
\hline \multirow[t]{2}{*}{ MY36B } & $(\mathrm{TG}) 7(\mathrm{GG}) 3$ & F:CCGTTGGTAAAGACGATAT & $251-283$ & 58 \\
\hline & & R:TGGTTGCGAGTTGGACAC & & \\
\hline \multirow[t]{2}{*}{ MZT46B } & $(\mathrm{TG}) 75$ & F:GACATAAAGGTTGTAGGGA & $151-283$ & 46 \\
\hline & & R:ATGGTAGTGATGATGCTTG & & \\
\hline
\end{tabular}

\section{Method}


Total DNA was extracted with SDS-phenol chloroform method. The PCR system used consisted of $1 \mu \mathrm{L}$ of template DNA (about $30 \mathrm{ng}$ ), $2 \mu \mathrm{L}$ of primer mix, 1 $\mu \mathrm{L}$ of universal fluorescent primers, $10 \mu \mathrm{L}$ of $2 \times$ Taq PCR MasterMix and $6 \mu \mathrm{L}$ of $\mathrm{ddH}_{2} \mathrm{O}$ to form a total volume of $20 \mu \mathrm{L}$. PCR program was as follows: predenaturation at $90^{\circ} \mathrm{C}$ for $5 \mathrm{~min}, 30$ cycles, denaturation at $94^{\circ} \mathrm{C}$ for $3 \mathrm{~min}$, annealing at $53^{\circ} \mathrm{C}$ for 1 min and at $72^{\circ} \mathrm{C}$ for $30 \mathrm{~s}$ and a final extension at $72^{\circ} \mathrm{C}$ for 10 min at the end of the cycle. The PCR products were subjected to capillary electrophoresis, and the electrophoresis patterns were genotyped by GeneMapper 3.7 and Peak Scanner software.

\section{Data Processing}

Pop32 software was utilised to calculate the number of effective alleles $(\mathrm{Ne})$, expected heterozygosity $(\mathrm{He})$, observed heterozygosity $(\mathrm{Ho})$ and gene flow $(\mathrm{Nm})$, genetic distance $(D s)$ and Shannon diversity index. Population clustering was analysed using the unweighted pair-population method with arithmetic means (UPGMA) of the MEGA 3.0 software. Analysis of molecular variance (AMOVA) was performed using Arlequin 3.11 software, and the genetic diversity and genetic differentiation index $\left(F_{\mathrm{ST}}\right)$ were computationally analysed.

\section{Results}

\section{Genetic diversity of the rainbow clam}

There were 1146 alleles successfully detected in the six populations through 17 SSR loci scanning the genomes of rainbow clam populations, except in the HGZ22 in the Wenzhou population failed to amplified by PCR. Except for the alleles detected at the two loci of HGZ2 and HGZ14, the remaining alleles were highly polymorphic loci, which indicated that the 17 microsatellite loci can be used to study the population genetics of rainbow clam (Table 3 ). 
Table 3

Analysis of Molecular Variance among Six Populations of Rainbow Clam

\begin{tabular}{|c|c|c|c|c|c|c|c|c|c|c|c|c|c|}
\hline pop & SSR & MH19A & Mi44A & MW15A & MX39C & MY36B & MZT46B & HGZ3 & HGZ6 & HGZ9 & Mir8 & Mir12 & Mir14 \\
\hline \multirow[t]{6}{*}{ ZS } & $\begin{array}{l}\text { Sample } \\
\text { No. }\end{array}$ & 96 & 100 & 100 & 98 & 84 & 96 & 100 & 100 & 100 & 96 & 96 & 94 \\
\hline & $\mathrm{Na}$ & 17 & 7 & 20 & 18 & 27 & 6 & 19 & 3 & 10 & 10 & 21 & 21 \\
\hline & $\mathrm{Ne}$ & 7.5789 & 3.3003 & 4.1391 & 3.2035 & 17.9086 & 2.3226 & 8.7260 & 1.1064 & 5.6243 & 5.8701 & 7.1888 & 4.3829 \\
\hline & Ho & 0.8542 & 0.9600 & 0.6200 & 0.8980 & 0.2619 & 0.8958 & 0.0400 & 0.0600 & 0.8800 & 0.8125 & 0.9583 & 0.8085 \\
\hline & $\mathrm{He}$ & 0.8772 & 0.7040 & 0.7661 & 0.6949 & 0.9555 & 0.5754 & 0.8943 & 0.0972 & 0.8305 & 0.8384 & 0.8700 & 0.7801 \\
\hline & I & 2.3251 & 1.3946 & 1.9772 & 1.8728 & 3.0815 & 1.0159 & 2.5069 & 0.2322 & 1.9486 & 1.9286 & 2.4370 & 2.0440 \\
\hline \multirow[t]{6}{*}{ ND } & $\begin{array}{l}\text { Sample } \\
\text { No. }\end{array}$ & 78 & 92 & 96 & 98 & 78 & 86 & 98 & 98 & 98 & 100 & 96 & 94 \\
\hline & $\mathrm{Na}$ & 18 & 8 & 30 & 10 & 15 & 24 & 8 & 14 & 2 & 8 & 9 & 10 \\
\hline & $\mathrm{Ne}$ & 11.7000 & 2.9782 & 11.1036 & 2.7805 & 18.2156 & 2.3012 & 5.5514 & 1.0416 & 5.2082 & 3.6928 & 3.3932 & 3.8518 \\
\hline & Ho & 0.7692 & 1.0000 & 0.8333 & 0.8163 & 0.4615 & 0.9767 & 0.0204 & 0.0408 & 1.0000 & 0.9800 & 0.9583 & 0.7447 \\
\hline & $\mathrm{He}$ & 0.9264 & 0.6715 & 0.9195 & 0.6470 & 0.9574 & 0.5721 & 0.8283 & 0.0404 & 0.8163 & 0.7366 & 0.7127 & 0.7483 \\
\hline & I & 2.6503 & 1.3328 & 2.8777 & 1.6638 & 3.0326 & 1.0217 & 2.0495 & 0.0996 & 1.7543 & 1.5876 & 1.4903 & 2.0490 \\
\hline \multirow[t]{6}{*}{$c x$} & $\begin{array}{l}\text { Sample } \\
\text { No. }\end{array}$ & 90 & 100 & 100 & 96 & 82 & 88 & 98 & 100 & 100 & 94 & 100 & 98 \\
\hline & $\mathrm{Na}$ & 22 & 5 & 30 & 18 & 28 & 5 & 11 & 4 & 15 & 11 & 6 & 18 \\
\hline & $\mathrm{Ne}$ & 11.3764 & 4.0750 & 6.7843 & 5.2364 & 15.0089 & 1.9979 & 2.4984 & 1.3369 & 6.8871 & 7.1143 & 2.9656 & 3.0703 \\
\hline & Ho & 0.9111 & 1.0000 & 0.9400 & 0.9167 & 0.6585 & 0.7045 & 0.7755 & 0.0000 & 0.9400 & 0.9362 & 0.9600 & 0.6735 \\
\hline & $\mathrm{He}$ & 0.9223 & 0.7622 & 0.8612 & 0.8175 & 0.9449 & 0.5052 & 0.6059 & 0.2545 & 0.8634 & 0.8687 & 0.6695 & 0.6813 \\
\hline & I & 2.7154 & 1.4715 & 2.5566 & 2.2264 & 2.9907 & 0.8671 & 1.3413 & 0.5388 & 2.2126 & 2.0765 & 1.2420 & 1.7969 \\
\hline \multirow[t]{6}{*}{$\mathrm{CM}$} & $\begin{array}{l}\text { Sample } \\
\text { no }\end{array}$ & 108 & 120 & 114 & 112 & 90 & 116 & 116 & 120 & 120 & 120 & 118 & 92 \\
\hline & $\mathrm{Na}$ & 21 & 5 & 17 & 15 & 25 & 9 & 11 & 5 & 11 & 8 & 22 & 10 \\
\hline & $\mathrm{Ne}$ & 12.7615 & 2.3614 & 4.3995 & 2.1261 & 8.8621 & 2.3168 & 1.4771 & 1.4682 & 3.9067 & 5.1173 & 6.0592 & 1.6067 \\
\hline & Ho & 0.9815 & 1.0000 & 0.3333 & 0.4464 & 0.4667 & 0.5690 & 0.1207 & 0.3500 & 0.9167 & 0.9500 & 0.7797 & 0.0870 \\
\hline & $\mathrm{He}$ & 0.9303 & 0.5814 & 0.7795 & 0.5344 & 0.8971 & 0.5733 & 0.3258 & 0.3216 & 0.7503 & 0.8113 & 0.8421 & 0.3817 \\
\hline & I & 2.7482 & 0.9969 & 1.9305 & 1.4246 & 2.6834 & 1.1756 & 0.8329 & 0.6585 & 1.6460 & 1.7885 & 2.3283 & 0.9337 \\
\hline \multirow[t]{6}{*}{ WZ } & $\begin{array}{l}\text { Sample } \\
\text { no }\end{array}$ & 100 & 98 & 96 & 56 & 82 & 76 & 96 & 100 & 100 & 100 & 100 & 56 \\
\hline & $\mathrm{Na}$ & 23 & 12 & 18 & 10 & 9 & 8 & 2 & 5 & 8 & 9 & 10 & 3 \\
\hline & $\mathrm{Ne}$ & 11.5207 & 3.6051 & 7.1331 & 1.6049 & 1.4038 & 2.3442 & 1.6528 & 1.5494 & 4.3365 & 5.3022 & 3.1250 & 1.1979 \\
\hline & Ho & 1.0000 & 1.0000 & 0.8333 & 0.3214 & 0.1220 & 1.0000 & 0.0000 & 0.3200 & 0.9600 & 0.9000 & 0.9600 & 0.0357 \\
\hline & $\mathrm{He}$ & 0.9224 & 0.7301 & 0.8689 & 0.3838 & 0.2912 & 0.5811 & 0.3991 & 0.3582 & 0.7772 & 0.8196 & 0.6869 & 0.1682 \\
\hline & I & 2.7197 & 1.6343 & 2.2915 & 0.9778 & 0.7424 & 1.0546 & 0.5841 & 0.7232 & 1.6415 & 1.7577 & 1.3815 & 0.3456 \\
\hline \multirow[t]{6}{*}{ LYG } & $\begin{array}{l}\text { Sample } \\
\text { No. }\end{array}$ & 98 & 100 & 94 & 100 & 72 & 86 & 94 & 100 & 100 & 92 & 100 & 100 \\
\hline & $\mathrm{Na}$ & 21 & 5 & 20 & 16 & 29 & 5 & 4 & 2 & 17 & 18 & 4 & 20 \\
\hline & $\mathrm{Ne}$ & 12.0957 & 3.9777 & 4.6456 & 2.0080 & 18.6475 & 1.9091 & 1.5314 & 1.0202 & 10.0402 & 10.2470 & 2.5316 & 2.7397 \\
\hline & Ho & 0.8571 & 1.0000 & 0.8085 & 0.5200 & 0.8056 & 0.3488 & 0.3830 & 0.0200 & 0.7000 & 0.6957 & 0.9600 & 0.6600 \\
\hline & $\mathrm{He}$ & 0.9268 & 0.7562 & 0.7932 & 0.5071 & 0.9597 & 0.4818 & 0.3507 & 0.0200 & 0.9095 & 0.9123 & 0.6111 & 0.6414 \\
\hline & I & 2.7247 & 1.4155 & 2.0706 & 1.3773 & 3.1140 & 0.9262 & 0.6279 & 0.0560 & 2.5136 & 2.5504 & 1.0406 & 1.7503 \\
\hline \multirow[t]{2}{*}{ Mean } & $\begin{array}{l}\text { Sample } \\
\text { No. }\end{array}$ & 95 & 101.7 & 100.0 & 93.3 & 81.3 & 91.3 & 100.3 & 103.0 & 103.0 & 100.3 & 101.7 & 89.0 \\
\hline & $\mathrm{Na}$ & 20.3333 & 7.0000 & 22.5000 & 14.5000 & 22.1667 & 9.5000 & 9.1667 & 5.5000 & 10.5000 & 10.6667 & 12.0000 & 13.6667 \\
\hline
\end{tabular}




\begin{tabular}{|llllllllllllll}
\hline pop & SSR & MH19A & Mi44A & MW15A & MX39C & MY36B & MZT46B & HGZ3 & HGZ6 & HGZ9 & Mir8 & Mir12 & Mir14 \\
\hline Ne & 11.1722 & 3.3830 & 6.3675 & 2.8266 & 13.3411 & 2.1986 & 3.5729 & 1.2538 & 6.0005 & 6.2240 & 4.2106 & 2.8082 \\
\hline Ho & 0.8955 & 0.9933 & 0.7281 & 0.6531 & 0.4627 & 0.7491 & 0.2233 & 0.1318 & 0.8995 & 0.8791 & 0.9294 & 0.5016 \\
\hline He & 0.9176 & 0.7009 & 0.8314 & 0.5975 & 0.8343 & 0.5482 & 0.5674 & 0.1820 & 0.8245 & 0.8312 & 0.7321 & 0.5668 \\
\hline$l$ & 2.6472 & 1.3743 & 2.2840 & 1.5905 & 2.6074 & 1.0102 & 1.3238 & 0.3847 & 1.9528 & 1.9482 & 1.6533 & 1.4866 \\
\hline
\end{tabular}

The average number of alleles among the 17 loci in 6 populations was 5.5000-22.5000 (17 loci average, 11.9039), the Ne was 1.2538-13.3411 (average, 5.1287), the Ho was $0.0100-0.9933$ (average, 0.5171 ), the He was $0.1820-0.9176$ (average, 0.6847 ) and the Shannon diversity index was $0.3847-2.6472$ (average, 1.6914).

The average number of alleles of the six populations was $8.3125-12.8235$, the Ne was $3.8135-5.7762$, and the Ho was $0.4381-0.6139$ (average, 0.5121 ). Amongst the populations studied, the $\mathrm{Ho}$ of $\mathrm{CX}$ was the highest, whereas the $\mathrm{Ho}$ of CM was the lowest. The average Hewas $0.6266-0.7325$ (average, 0.6847 ). The Zhoushan population was the highest, whereas the Wenzhou population was the lowest. The average Shannon diversity indices were 1.7998 (ZS), 1.7451 (CX), 1.6603 (ND), 1.6941 (LYG), 1.6355 (CM) and 1.2655 (WZ). These results showed that, although the genetic diversities of the six wild populations of rainbow clam were different, the overall genetic diversity was high (Table 3 ).

\section{Phylogenetic Relationships Of The Six Populations Of Rainbow Clams}

\section{AMOVA}

AMOVA of the six different geographical populations of rainbow clams showed that $4.70 \%$ of their genetic variation could be derived from the population, whilst $95.30 \%$ of their variation was from within the population. The $F_{\mathrm{ST}}$ of the populations was 0.0470 , indicating that the degree of genetic differentiation amongst the populations was low (Table 4).

Table. 4 Analysis of Molecular Variance among Six Populations of Rainbow Clam

\begin{tabular}{|c|c|c|c|c|}
\hline Source of variation & d.f. & Sum of square & Variance component & Percentage of variation $₫ \% \bigotimes$ \\
\hline Among populaions & 5 & 100.815 & $0.16327 \mathrm{Va}$ & 4.70 \\
\hline within populations & 614 & 2031.833 & 3.30917 Vb & 95.30 \\
\hline Total & 619 & 2132.648 & 3.47245 & \\
\hline Fixation Index & $F_{\mathrm{ST}}:$ & $0.04702 \varangle \mathrm{P} \otimes 0$ & & \\
\hline
\end{tabular}

\section{Genetic Distance}

The Ds amongst the six populations of rainbow clam was $0.0668-0.3020$. The Ds between the Wenzhou and Zhoushan populations was the largest (0.3020), and their genetic relationship was far. By contrast, the $D s$ between the Lianyungang and Cixi populations was the smallest (0.0668), and their genetic relationship was relatively close (Table 5).

Table. 5 Nie's unbiased genetic distance of 6 populations of rainbow clams

\begin{tabular}{lllllll} 
Populations & ZS & ND & CX & LYG & CM & WZ \\
\hline ZS & & & & & \\
\hline ND & 0.1196 & & & & \\
\hline CX & 0.1680 & 0.1921 & & & \\
\hline LYG & 0.2157 & 0.2540 & 0.0668 & & \\
\hline CM & 0.2297 & 0.1986 & 0.1160 & 0.1140 & \\
\hline WZ & 0.3020 & 0.2292 & 0.2204 & 0.2185 & 0.1228
\end{tabular}

Table 6. Genetic similarity coefficient and gene flow between 6 populations of rainbow clams Genetic similarity coefficient above the diagonal, gene flow below the diagonal. 


\begin{tabular}{lllllll} 
Populations & ZS & ND & CX & LYG & CM & WZ \\
\hline ZS & $\star \star \star \star$ & 10.4019 & 6.0283 & 3.7538 & 2.9146 & 3.4532 \\
\hline ND & 0.0235 & $\star \star \star \star$ & 4.9507 & 3.3291 & 3.6003 & 6.2250 \\
\hline CX & 0.0398 & 0.0481 & $\star \star \star \star$ & 13.2635 & 6.1635 & 7.1116 \\
\hline LYG & 0.0624 & 0.0699 & 0.0185 & $\star \star \star \star$ & 5.4267 & 5.7052 \\
\hline CM & 0.0790 & 0.0649 & 0.0390 & 0.0440 & $\star \star \star *$ & 9.2629 \\
\hline WZ & 0.0675 & 0.0386 & 0.0340 & 0.0420 & 0.0263 & $\star \star \star *$
\end{tabular}

\section{Genetic Differentiation Index And Gene Flow}

Amongst those of the different populations, the $F_{\mathrm{ST}}$ between the Chongming and Zhoushan populations was the highest (0.0790), whereas that between the Cixi and Lianyungang populations was the lowest (0.0185). The $\mathrm{Nm}$ values between the Lianyungang and Cixi populations and that between the Ningde and Zhoushan populations were 13.2635 and 10.4019 , respectively; the $\mathrm{Nm}$ between the Chongming and Zhoushan populations was 2.9146 . The total $F_{\text {ST }}$ between populations was $0.04702 ; F_{\mathrm{ST}}<0.05$ indicates a low degree of genetic differentiation, which, in turn, reveals rich genetic diversity. The overall differentiation degree amongst populations was low.

\section{Cluster Analysis}

On the basis of the genetic distances amongst the populations, a clustering map was constructed using the UPGMA method of MEGA3.0 software. The six populations of rainbow clam could be divided into the following three branches: LYG and CX in the first branch, CM and WZ in the second branch and ZS and ND in the third branch.

\section{Discussion}

$F_{\mathrm{ST}}$ is an important parameter for measuring the degree of genetic differentiation in a population. A large $F_{\mathrm{ST}}$ value indicates a high degree of differentiation between populations. No differentiation exists when $F_{\mathrm{ST}}$ is $0-0.05$, moderate differentiation is observed when $F_{\mathrm{ST}}$ is $0.05-0.15$, high differentiation is obtained when $F_{\mathrm{ST}}$ is $0.15-0.25$ and great differentiation is found when $F_{\mathrm{ST}}>0.25$ (Hartl and Clark 1997). In this study, the $F_{\mathrm{ST}}$ of the six populations under study was 0.047 (<0.05). Overall, the differentiation between the populations was minimal at best. However, the $F_{\mathrm{ST}}$ values of the ZS-LYG, ZS-CM, ZS-WZ, LYG-ND and CM-ND populations were in the range of 0.0624-0.0790 (0.05), which indicates that moderate genetic differentiation existed between the Zhoushan and each of the Lianyungang, Chongming and Wenzhou populations and between the Ningde and each of the Lianyungang and Chongming populations of rainbow clams. $\mathrm{Nm}$ can indicate the degree of genetic differentiation in a population. If $\mathrm{Nm}<1$, genetic differentiation occurs amongst populations. If $\mathrm{Nm}>1$, genetic differentiation is relatively low. If $N m>4$, genetic differentiation is very low (Ratnaningrum et al. 2017). The results of AMOVA showed that the $N m$ values amongst the six populations of rainbow clams lay between 2.9146 and 13.2635 , and the Nm values amongst the ZS-LYG, ZS-CM, ZS-WZ, LYG-ND and $\mathrm{CM}-\mathrm{ND}$ populations were greater than 1 and less than 4 . These results indicate low genetic differentiation amongst these populations. In the present study, the sampling area of rainbow clam was distributed in Yellow Sea and East China Seas. LYG and CM are in Yellow Sea, with a geographical distance (about $1000 \mathrm{~km}$ coastline), and no differentiation between these populations was observed $\left(F_{\mathrm{ST}}=0.0040<0.05\right)$. Although the geographical distance between the Chongming and Zhoushan populations is close, the Yangtze estuary is situated between them. Inflow of the Yangtze River lowers the salinity of the sea water and, hence, obstructs the passage of larvae and hinders gene communication to some extent (the $\mathrm{Nm}$ for CM-ZS is 2.9146); therefore, moderate genetic differentiation occurs between the $\mathrm{CM}$ and ZS populations $\left(F_{\mathrm{ST}}=0.0790\right)$. Xu $(2016)$ analysed the population morphology and genetic diversity of rainbow clams from Zhejiang and revealed that the Zhoushan population have a great variation from the Yueqing, Taizhou and Wenling populations $\left(G_{S T}=0.2479\right)$. Present study also indicated genetic differentiation occurred in the Zhoushan population $\left(F_{\mathrm{ST}}=0.2479\right)$ which was consistent with Xu $(2016)$, who showed that the Zhoushan population of rainbow clam presents moderate genetic differentiation.

This study also found that the degree of genetic differentiation between rainbow clam populations is not related to the geographical distance. Although the geographical distance between LYG and CX was relative far away, the $F_{\mathrm{ST}}$ value between the LYG and CX populations of rainbow was very low, only 0.0180 (< $0.05)$, which indicated a lack of genetic differentiation between the two populations. Gene exchange between the two populations occurred very frequently $(\mathrm{Nm}=13.2635>4)$. The inconsistency of the relationship between degree of genetic differentiation and geographical distance has previously been observed in different populations of Coelomactra antiquata. Meng (2013) showed that the population genetic differentiation between the $C$. antiquata from the Southeastern Sea and that from the Yellow Sea in Lianyungang and Rizhao is not obvious basing on the results of ITS2 and 16 SrRNA for six populations of $C$. antiquata in the coasts of China. By contrast, the difference between the Guangxi and Fujian populations, which have a relatively close geographical distance, reached the interspecies level. The real reason may be from human activity such as artificial farming and introduction, but more detailed reasons still were unknown so far. 
Genetic diversity, including the degree of genetic variation and the genetic structure of the population, is an important basis for evaluating the status of a genetic resources. A higher genetic diversity of a population results in a stronger adaptability to the living environment and a greater potential for evolution (Tian et al. 2013). The genetic diversity of a population is mainly manifested in two aspects: heterozygosity and number of alleles (Yu et al. 2012). Many reports have explored the genetic diversity of aquatic animals by using SSR markers. Li et al. (2011) studied the population genetics of Portunus trituberculatus by microsatellite markers and found an average Ho of 0.2222-1.0000 and an average He of 0.4367-0.9099. Li et al. (2009) used SSR technology to measure the average $\mathrm{Ho}(0.32-0.49)$ of wild and cultured populations of scallops and found an average $\mathrm{He} 0.37-0.55$. Chang et al. (2007) analysed the genetic diversity of five populations of scallops $P$. yessoensis in China and abroad and found an average $\mathrm{Ho}$ of $0.2708-0.3292$ and average $\mathrm{He}$ of $0.3620-0.4595$ for the five populations. Tian et al. (2013) used 20 microsatellite markers to determine the Ho and He of four populations of Tetranychus quinquefasciatus found ranges of 0.667-0.9667 and 0.6198-0.9318, respectively. An et al. (2012) studied the genetic structure of five wild-type populations of $C$. philippinarum in two sea areas of Korea by using seven SSR markers and noted high genetic diversity amongst the clams (total $H e=0.813$ ). The results of the present study revealed that the average $\mathrm{Ho}$ of the six populations of rainbow clam was between 0.4381 and 0.6139 , and the $\mathrm{He}$ was $0.6266-0.7325$ and the value of Hewas as follows: ZS (0.7325), CX (0.7162), ND (0.6839), LYG (0.6786), CM (0.6701) and WZ (0.6266). The average number of alleles of the 17 loci in the six populations ranged from 5.5000 to 22.500, and the Ne was between 1.2538 and 13.3411 . The genetic diversity of the rainbow clams was higher than those of bay scallop Argopecten irradians and scallop P. yessoensis; this genetic diversity is similar to the He of four populations of clams $T$. quinquefasciatus and lower than that of five populations of clam C. philippinarum. Generally, in present study He (0.7325) and Shannon diversity index (1.7998) were the highest in the Zhoushan population which indicated the Zhoushan population has the richest genetic diversity amongst the clam populations studied.

\section{Conclusions}

The six populations of rainbow clams all presented high genetic diversity, which reflects the good protection and development prospects of rainbow clam resources in China. These results would be useful to genetic breeding practice and resources management.

\section{Declarations}

\section{Acknowledgments}

We greatly acknowledge following colleagues for their great help and support in the process of investigation and sampling for rainbow clam: Dr. Feng Zhao from East China Sea Fisheries Institute of CAFS for the specimen in East Beach of Chongming Island, Pro. Binlun Yan from Huaihai Institute of Technology for the specimen in Sanyang harbor of Haizhou bay, Dr. Zehui Hu from Marine Fisheries Research Institute of Zhejiang of China for the specimen in Datian Bay at Daishan of Zhoushan,

Mr. Chen from Xiabaishi at Sansha bay in Fu'an for the specimen in the site, Pro. Meizheng Wang from Institute of Cixi Fisheries for the specimen in Cixi Sanbei shoal at Hangzhou Bay, Dr. Weicheng Lui from Zhejiang Mariculture Research Institute for the specimen in Simon Island at Yueqing Bay.

\section{Funding}

This study was supported in part by grants from the Modern Agricultural Industry Technology System of China Key (No. CAR49), the National Natural Science Foundation of China (No. 31101900 ) and the Priority Academic Program Development of Jiangsu Higher Education Institutions.

\section{Compliance with ethical standards}

\section{Conflict of interest}

All authors declare that they have no conflict of interest in the publication.

\section{Ethical approval}

All applicable international, national and/or institutional guidelines for the care and use of animals (invertebrates) were followed.

\section{Sampling and field studies}

The necessary permit for sampling and observational field studies have been obtained by the authors from the competent authorities and are mentioned in the acknowledgements.

\section{References}

1. An HS, Kwang KJ, Cho KC, Han HS, Myeong Jl (2012) Genetic structure of Korean populations of the clam Ruditapes philippinarum inferred from microsatellite marker analysis. Biochem Syst Ecol 44:186-195

2. Bai Z, Han X, Luo M, Lin J, Wang J, Li J (2015) Constructing a microsatellite-based linkage map and identifying QTL for pearl quality traits in triangle pearl mussel (Hyriopsis cumingii). Aquaculture 437:102-110

3. Cui HY, Ma HL, Ma CY (2011) Genetic diversity among different families of mud crab Scylla paramamosain by microsatellite markers. Mar Fish 33:274281

4. Chang YQ, Chen XX, Ding J (2007) Genetic diversity in five scallop populations of the Japanese scallop (Patinopecten yessoensis). Ecol J 27:1145-1152 
5. Hartl DL, Clark AG (1997) Principles of population genetics. 3rd edition, Sunderland, MA: Sinauer Associates Inc

6. Ji YB, Li TW, Su XR (2007) Preliminary study on biological characteristics of rainbow clam in Zhejiang coast. Fish Sci 26:494-496

7. Lv GT, Zhang XM, Zhao J (2012) The Effect of Phenotypic and Morphometric Traits on Body Weight of Moerella iridescens. J Zhejiang Ocean Univ: Nat Sci Edit 31:487-491

8. Li X, Liu P, Song X (2011) Construction on enriched microsatellite library and characterization of microsatellite markers from swimming crab. J Fish Sci China 18:194-201

9. Li HJ, Liu X, Du XD, Song R, Zhang GF, Hu JJ, Bao ZM (2009) Development and isolation of microsatellite markers in bay scallop. Mar Sci 33:3-8

10. Meng XP, Shen X, Zhao NN, Tian M, Zeng Y, Chen JA, Dong ZG, Cheng HL, Tian JT, Liu ZH, Yang AG, Wu B, Zhou LQ (2013) Microsatellite analysis of genetic diversity in four geographic populations of Sca parc brughtonii. Prog Fish Sci 34:59-67

11. Ratnaningrum YWN, Indrioko S, Faridah E, Syahbudin A (2017) Gene flow and selection evidence of sandalwood (Santalum album) under various population structures in gunung sewu (Java, Indonesia), and its effects on genetic differentiation. Biodiversitas 18:1493-1505

12. Tian JT, Liu ZH, Yang AG, Wu B, Zhou LQ (2013) Microsatellite analysis of genetic diversity of 4 geographic populations of clam. Prog Fish Sci 6:59-67

13. Xu H, Hu YL, Xu YP, Jin K, Chen P (2016) The analysis of genetic diversity and morphology of Moerella iridescens in Zhejiang Province. J Shanghai Ocean Univ 4:508-514

14. Yu ZF, Yan XC, Zhang YH, Yang F, Yang F, Zhang GF (2012) EST-SSR diversity of Philippines clam in different age groups in Dalian. Acta Ecol Sin 1:46734681

15. Zhao Y, Zhu X, Sun X (2010) Microsatellite diversity in cultured populations of rainbow trout Oncorhynchus mykiss in China. J Fish Biol 73:1249-1255

\section{Figures}

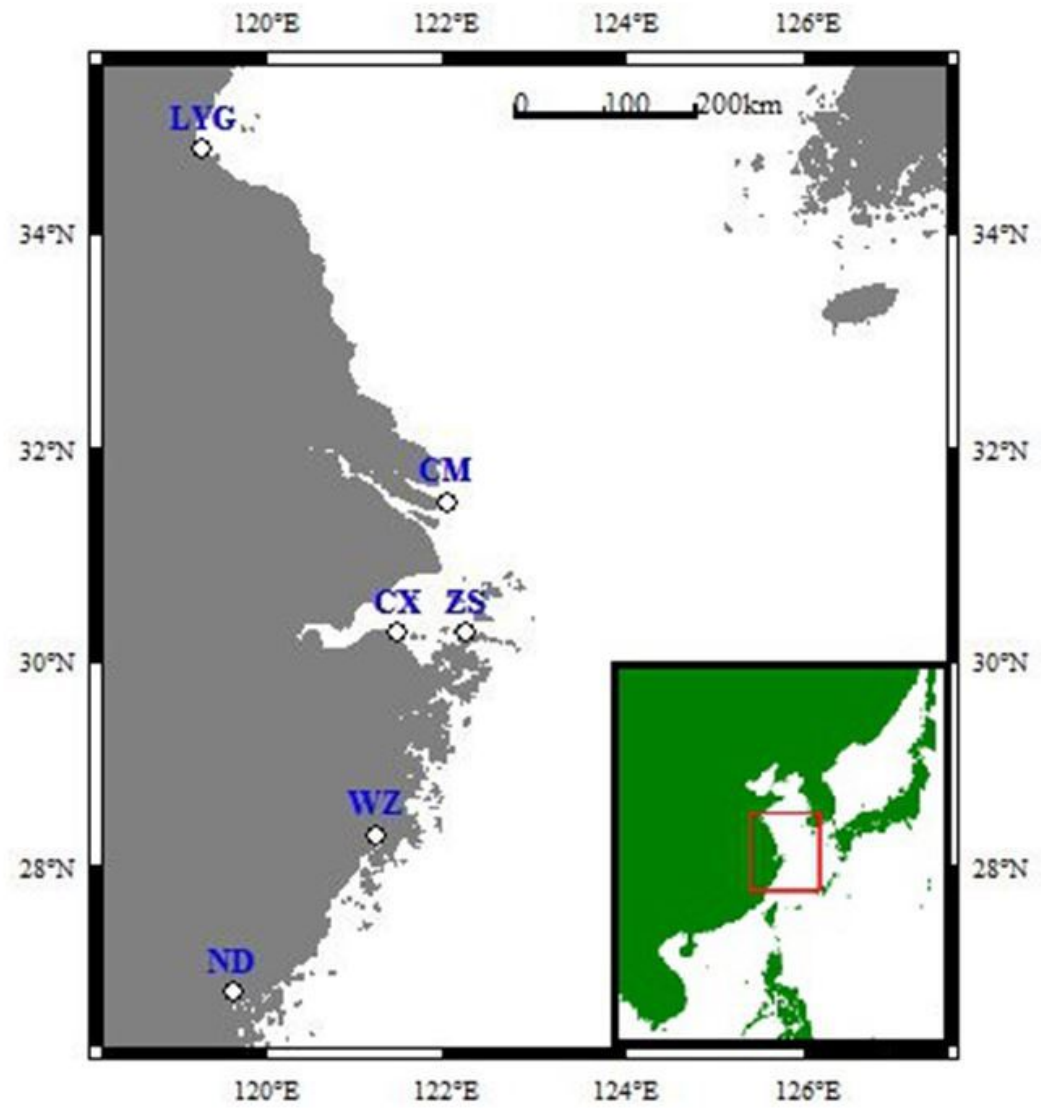

\section{Figure 1}

Sample collection map of rainbow clam in coastal China. 


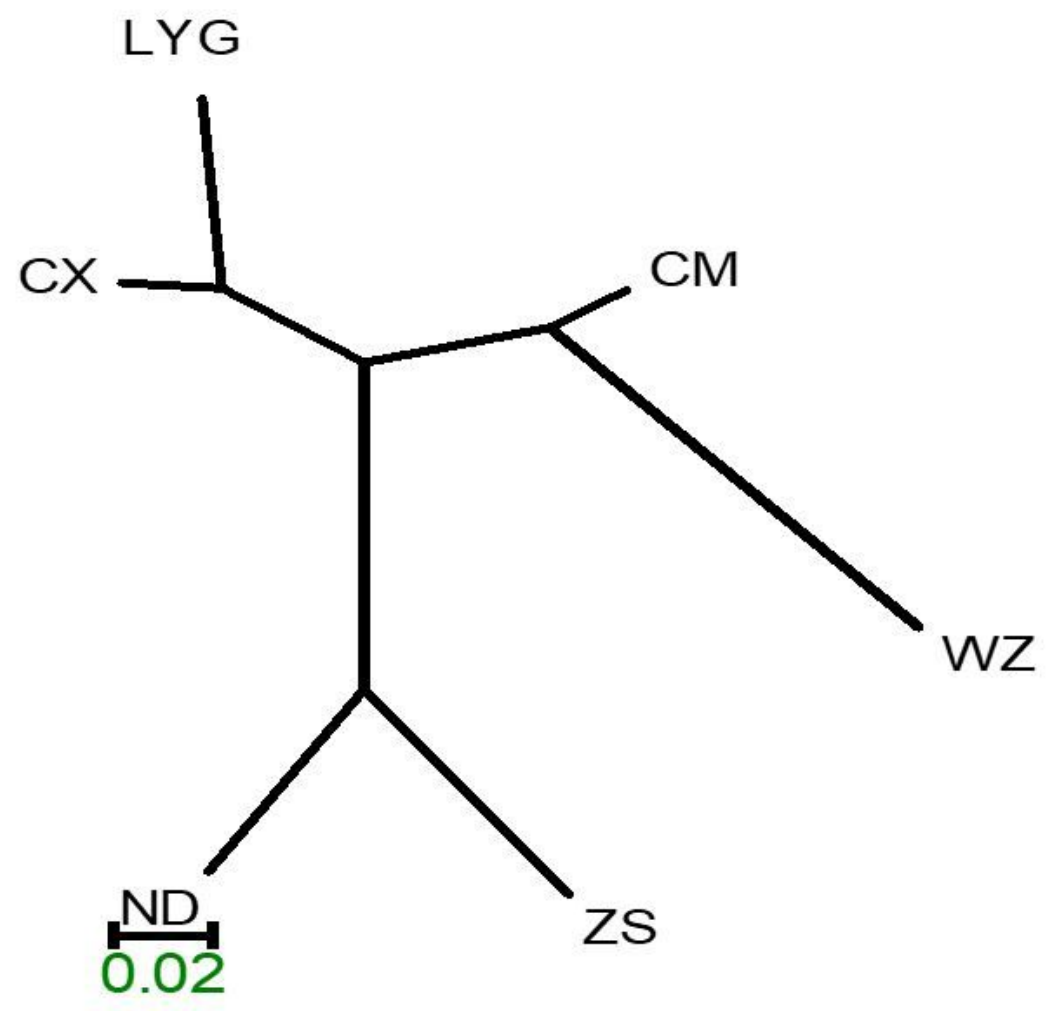

Figure 2

Rainbow clam 6 populations of UPGMA trees

Page $10 / 10$ 